\title{
Women's Leadership and Participation in Recent Christian Formations in Swaziland: Reshaping the Patriarchal Agenda?
}

\section{Sonene Nyawo \\ ORCID iD: https://orcid.org/0000-0003-3542-8034}

\begin{abstract}
Swaziland $^{1}$ is experiencing a proliferation of new religious bodies, as elsewhere in Africa, including emerging expressions of Christianity established by women. In this strongly patriarchal context, women, through recent Christian formations, go against the grain, and become pastors, evangelists, prophets and healers. The questions are, how do women appear to blend in when they take the lead in creating ecumenical associations? How do they constitute their own spaces within patriarchy, whilst accomplishing ecumenically inclusive Christian fellowship among themselves? The answers are provided through a case study of Mhlabuhlangene Prayer Group (MPG). It is argued that Christian women engage, not in resistance, but in negotiation, which keeps a model of their relationships and their spirituality in conformity with the patriarchal agenda. The case demonstrates in detail the occasions and activities through which women create their own spaces of Christian devotion whilst they simultaneously affirm patriarchal values. My data was generated from a particularly significant sample and through participant observation, which provide evidence that MPG is an ecumenical movement that 'builds on the indigenous'. However, the paper argues that the women's compliant approach to expressing their spirituality requires certain modifications, which are meant to lead to full inward empowerment.
\end{abstract}

Keywords: feminism, leadership, participation, Christian formations, patriarchy

${ }^{1}$ In April 2018, King Mswati III changed the name of the country from Swaziland to Kingdom of Eswatini. The initial rendition is retained in this article. 


\section{Introduction}

Since the end of the $19^{\text {th }}$ century, Christianity in Africa has been characterised by rapid expansion. Its expansion since the $20^{\text {th }}$ century has been so dramatic that Hollenweger (1972) claims that 'the center of gravity' of the Christian faith has shifted from the northern to the southern continents. This assertion has been reiterated by scholars like Sanneh (2003); Jenkins (2002); and Walls (2002), who are interested in theological and historical developments of Christianity in developing countries. There is no doubt that this phenomenal growth of Christianity has been unfolding even faster than had originally been anticipated by scholars. In addition to the traditional forms of Christianity established by missionaries, Africa hosts African independent churches that emerged from the initial interaction between Africa and the West, and which are a product of the revival of Christianity all over the world. This manifestation of Christian presence in Africa has generated renewal and a proliferation of Pentecostal and charismatic ministries that have gained significance in every country in Africa. The new development in Pentecostal Christianity is what scholars have labelled as neo-Pentecostalism (Anderson 1995) and charismatic ministries or churches (Asamoah-Gyadu 2000). These new Christian groups have a strong belief in the baptism of the Holy Spirit and related gifts of the Spirit, such as speaking in tongues (glossolalia), healing, and prophecy (Hollenweger 1997).

Like the rest of Africa, Swaziland has experienced a proliferation of new religious bodies, leading to new, emerging expressions of Christianity established by women. These women-led Christian formations, known as prayer groups, assume the typically Pentecostal enthusiasm and experiential approach to religious practice. As members of ecumenically inclusive fellowships, the members view society as being in a state of crisis, to which spiritual activities, such as prayer and worship, are the appropriate response. Mhlabuhlangene (meaning united nations) Prayer Group (MPG) is one of these groups that exhibits neo-Pentecostal traits in its expressions of spirituality.

Premised on this background, data generation for the article employed a qualitative research paradigm, framed within an exploratory and critical research design. The article sought to ascertain ways through which Christian Swazi women create their spaces within a patriarchal context through the establishment of prayer groups. MPG serves as a case study to illustrate the less resistant approach women employ in ecumenically inclusive women-led 
Christian fellowships, whilst they conform to patriarchy. Employing qualitative techniques, therefore, enabled me to engage the participants in intensive interviews, which sought to ascertain how they negotiate with patriarchy while expressing their spiritualties in self-crafted spaces within a patriarchal context.

\section{Locating the Social Context}

The Kingdom of Swaziland is the second-smallest country and last absolute monarchy in Africa. It is located on the eastern edge of the African plateau, and is bordered by the Republic of South Africa and the Republic of Mozambique. Estimates based on the most recent population census data (Kingdom of Swaziland 2007) put Swaziland's total population at slightly over 1 million. About 53\% of this population are women. Swazis share a common language and a common set of traditional values, in a society that is both modern and traditional. The power of tradition is so pervasive in Swaziland that the modern and traditional forms of practice are, more often than not, collapsed into one. The cultural traditions are preserved as cultural heritage by the institution of the monarch and male figures of society.

Swazi society is patriarchal ${ }^{2}$. Abundant evidence from literature shows how masculine and feminine gender roles and perceptions are socially constructed in Swazi families, with the bulk of the responsibility for reproduction being placed on women. A Baseline Study of the Socio-economic Impact of HIV and AIDS and the Responsiveness of Policy Framework Swaziland (AWEPON 2005) describes culture as the conduit for the institutionalisation of inequalities and discriminatory practices against women. Mpofu (1983) traces the start of a woman's subservience to her birth as a girl in a family. He argues that it is not marriage that changes the status of a woman; a woman has always been and remains minor, attached to a male figure

${ }^{2}$ Patriarchy is a social system in which the role of the male as the primary authority figure is central to social organisation, and where fathers hold authority over women and children, and property. There have been controversies about the term patriarchy, but in recent years most forms of feminism tend to agree that patriarchy is a general descriptor of male dominance. See Malti-Douglas, Fedwa (2007). Encyclopedia of Sex and Gender. Detroit: Macmillan. 
throughout her life - this is what Oduyoye (1995) calls a compulsory attachment to men. Zigira (1998), in a study entitled, Role of NGOs in Economic Empowerment of Women in Swaziland, notes that unequal gender relations exist in marriages, and they impede women's potential to achieve sustainable development. He states, 'it is within the family that social construction of womanhood is engineered and perpetuated, and in which process women become unwilling partners to even critique culture'. Women and the Law in Southern Africa Swaziland Chapter (WLSA 2001) also asserts that the interest and position of a family member are compromised by being born female. From birth, the female child is perceived to be a temporary member of the family, and when she marries, she occupies an inferior position as a newcomer, an outsider and a non-blood member of her new family, until she produces children, who become the family heritage (Ngcobo 2007).

Swazi society is patriarchal by nature, and it has a unique history regarding the transmission and growth of Christianity. It is believed that Christianity was introduced in Swaziland in 1844, at the initiative of a cultural figure, King Somhlolo ${ }^{3}$, and it spread after his death through missionary expansion. As a result, Swaziland's socioeconomic and political ideology is built upon its culture and the Bible; thus, culture and religion form an intricate and intertwined web. If asked about religion, almost every Swazi would claim to be a Christian. According to US Department of State (2018) Report on international Religious Freedom most of Swaziland's population is Christian, with about $40 \%$ of the population affiliated with Zionist churches, who profess a blend of Christianity and traditional religion. About $20 \%$ of the population is Roman Catholic, and other Christian denominations (30\% of the population) include Anglicans, Methodists, Evangelicals and Charismatics; the latter is also known as Ministries. Less than 10\% of the population are Muslim and members of other small groups, including Jewish, The Church of the Latterday Saints and Bahai communities. These statistics confirm those of the Swazi

${ }^{3}$ It is believed that King Somhlolo had a vision whilst performing national rituals; he saw white men coming from the east, carrying a book (the Bible) in the right hand and a coin (money) in the left hand. God instructed him to advise the Swazi to 'eat' the book and reject the money. See Mzizi (2003). Churchstate tensions in the Kingdom of Swaziland: Honest dishonesty or dishonest honesty? BOLESWA Journal of Occasional Papers in Theology \& Religion 1: $7-22$. 
2007 Census (Kingdom of Swaziland, 2007), which reports that about $90 \%$ of Swazis are adherents of the Christian religion.

\section{Gender, Power and Leadership in Swaziland}

In the broader international literature, feminists have long analysed familial relations that favour men in the intrafamilial distribution of power and resources. Moghadam (2005) and other scholars have linked this power to the way families are constructed in patriarchal systems, where family is conceptualised as an essential social unit. Men assume exalted positions within the family structure, whilst women are relegated to a minority status. This power differential is clearly evident in Swazi social organisation. Studies undertaken in Swaziland (Nyawo \& Nsibande, 2014; WLSA 2001; Zigira, 1998) show that, although there are more women in Swaziland than men, women's power is far less than that of men; women continue to inhabit a subordinate segment of society. Representation of women in many sectors of society is still unequal, with most women occupying no more than middle management or low-status professions, with little or no decision-making power; boardrooms are still dominated by men. It is argued in the training manual of CEDAW, Gender, Leadership and Advocacy for Members of Parliament (2011:16), that,

negative stereotyping, systematic and institutionalized oppression of women as well as training women to settle for less instead of wanting the best for themselves and their lives are some of the blockages that society uses to deny women opportunities in areas such as leadership.

A scenario describing the lack of representation of women in leadership positions is reported by Nyawo and Nsibande (2014), who conducted a study with 21 female school leaders to ascertain the extent to which sociocultural factors impact on gender equality in accessing leadership positions at schools in Swaziland. The study reveals that longstanding patriarchal heritage persists and continues to define gender relationships in all subsystems in Swaziland. The authors conclude that social institutions can never be neutral, because they are active supporters and faithful reflectors of the status quo. Hence, this article recommends that women, instead of fighting against the norm, should adjust 
within the patriarchal space to make sense of their Christian expressions. MPG is a classic example, as revealed by data generated from members' experiences and narratives.

\section{Do Women 'Feel at Home' in Neo-Pentecostal Churches?}

Neo-Pentecostal churches (NPCs) are active in public spaces and hostels, bars, schools, social halls and cinema, all of which have been turned into churches (Hollenweger 1997). In the northern hemisphere, churches have been closing down and church buildings have been turned into social halls or museums. In contrast, in Africa, there is evidence of a revival of Christianity (AsamoahGyadu 2000). Though there is little if any statistical evidence of this growth in Christianity, what is clear is that it has found fertile ground among women who feel alienated in mainstream Christianity. High membership numbers in NPC is confirmed by Anderson (1995:284), who observes,

It shares the generally fissiparous nature of the Pentecostal movement. In a context where people's choice of religion is determined by its ability to produce results and deal with their existential questions, this can hardly be otherwise. Just as the traditional gods are followed as long as they produce expected results, so is the Neo-Pentecostal movement able to attract people as long as they can discern the anointing of God upon a particular church or fellowship and its leadership.

As reported by Asamoah-Gyadu (2000) and other scholars, women are the majority in NPCs in Africa, and that is overwhelming evidence that 'they feel at home' as active participants in God's ministry. Their congregations offer fellowship and support in prayer, particularly to people who feel marginalised. Women also attain a new identity in these new Christian expressions. They receive affirmation, as the churches provide them with mechanisms to cope with the stress of extended family life, family conflicts and social disintegration created by a rapidly changing society. They share a caring support network outside the formal structures of society, which present opportunities for personal achievement. They are also accorded recognition through assuming significant roles as pastors, prophetesses and bishops, hence mediators of God's grace and spirit over humanity. 
An example of a female leader, who founded one of the fastest growing NPCs, is Bishop Margaret Wanjira of Jesus Is Alive Ministries in Kenya. According to Mwaura (2005) members of the church accepted Bishop Wanjira's leadership, despite that she was an unmarried single mother. They held her in high esteem as a person with God's anointing. To the church, her gender and status were irrelevant because she had been 'renewed in Christ'. However, Bishop Wanjira confessed that she had been subjected to insults because of her personal status. She derived fulfilment in being a woman, and this had endeared her to her followers, particularly single mothers. Her deliverance ministry was particularly appealing to those who perceived themselves to be victims of witchcraft, misfortune and afflictions of life attributed to the devil and his demons. She presented to them a comprehensive theology of salvation that encompassed new life and victory over all evil. Members could identify with her easily, since she was delivered from the forces of evil, she understood affliction, poverty, prostitution, hunger and all wants.

Not only are women's needs, both spiritual and otherwise, met in these NPCs, they are also made to feel important. Usually, single mothers, unmarried women, and divorced or separated women have no roles in some mainstream churches and may be barred from holding office in church leadership. However, NPCs in Africa welcome and affirm them. Since power is charismatic, they, too, can be channels of divine power (Asamoah-Gyadu 2000). However, despite empowerment of women in some NPCs by the liberating hermeneutic of their reading of scripture, some societies demonstrate ambivalent attitudes towards women. Hackett (1998:216) explains:

At one level women may enjoy greater participation and leadership opportunities in God's army, whilst at another level they are frequently stigmatized and demonized, notably those of the unmarried and 'liberated variety'.

Despite these diffident attitudes towards women as leaders, there are women who are so empowered that they are able to swim against the tide, and they experience what Mwaura (2005:47) calls 'ministerial freedom'; they are able to preach, heal, prophesy and exorcise demons. MPG, also classified as an NPC, is an example of a charismatic religious body that enjoys 'ministerial freedom' to practise it spiritual gifts, though within patriarchal frameworks. 


\section{Theoretical Considerations: African Women's Anthropology}

Reflections in this article are drawn on African women's anthropology, which advances that patriarchal structures were created by one gender in time immemorial to institutionalise the alleged inferiority of women before men (Oduyoye 2001). Stereotypical generalisations on genders are passed down through generations and are reinforced through religio-cultural and Christian institutions. The African women's anthropology approach takes cognisance of culture as an indispensable variable within gender discourse in Africa, and argues that culture shapes and influences the experiences of African women (Kwok 2001). As noted by Phiri (2004), culture is a social construct that assigns roles to women and men based on how society understands the identities of women and men. Whilst Phiri acknowledges that culture is important, because it gives people their identities, she also asserts that, 'unfortunately African cultures have viewed women as less important than men, thereby making it difficult for women to have valid relationships with self, others, creation and God' (Phiri 2004:17). Hence, culture can provide women with communal identity and a sense of belonging. At the same time, culture can be manipulated and used as a tool of domination. Kanyoro (2001), Oduyoye (2001), Phiri (2004) and Nadar (2009) have theorised about the humanity of African women and how it is intricately tied with religio-cultural and social expectations of women's subordinate status. Moyo (2004) perceives these societal expectations as being bred in religo-cultural and Christian institutions, which socialise women to believe that they are custodians of acceptable beliefs and behaviours in a patriarchal space.

At the heart of this paper is the argument that Swazi women can, using the example of MPG, take the lead in forming ecumenical associations through establishing women-led prayer groups. However, as they create their own spaces of Christian devotion, they will practice their spirituality within the poles of patriarchy; by doing so, they intentionally and mostly unintentionally affirm the patriarchal agenda.

Related to the African women's anthropology approach on which the article draws, is African feminist pneumatology, a perspective which, according to Kaunda and Phiri (2016), emphasises the intersectionality of African cultures, women's experiences, spiritual empowerment and the Holy Spirit. In their insightful comment about women's experiences with the Holy Spirit, Kaunda and Phiri (2016) assert that it empowers women to resist unjust relations of power in the church, by enabling them to practice their spiritual 
gifts on equal ground with their male counterparts, whilst the women are empowered to deal with multiple oppressions (Asamoah-Gyadu 1998). For Asamoah-Gyadu, this confirms that God's call to women is real and active, rather than passive. He refers to women-led ministries, which, he says, are legitimised by their leaders having had encounters with God through conversion experiences, who were subsequently endowed with divine powers, which manifest in their ability to heal and deliver people from demons.

The gist of the argument in this paper is that women at MPG do have experiences with the Holy Spirit, and they exercise their gifts of leadership, prophesy and healing. However, patriarchy is a deeply rooted social construct that manages to exert pressure on them to conform, instead of challenging it.

\section{Feminist Research Methodologies}

The article is located within a qualitative critical feminist paradigm. Nadar 2014:20) lists the key characteristics of feminist methods of research as embracing a 'suspicion of master narratives of knowledge', encouraging creative use of tools for knowledge gathering and dissemination, promoting subjectivity and reflexivity within the research process and, most importantly, empowering participants during the process. Put simply, feminist methods affirm that the process of research is as important as the product. Mama (2011:13) emphasises that, in feminist research,

it is clear that despite the pressure to remain within positivist conventions, feminist researchers in the region have sought to give voice to women through methods that allow and encourage the articulation of previously unavailable narratives - story telling, oral histories, biographies and life stories reflect growing awareness of the limits of the androcentric archive and the colonial and postcolonial information systems that have silenced women and suppressed their perspectives.

This article, therefore, has a section on data presented in the form of narratives. I report narratives shared by four participants in their testimonies on how they experience God at MPG. Nadar, in her article, Her-stories and HerTheologies: Charting Feminist Theologies in Africa (2009), identifies storytelling, specifically, as a key method used by African women to make theological sense of their experiences in patriarchal societies. 


\section{Location of the Interviews}

Table 1 Profiles of participants

\begin{tabular}{|l|l|l|l|l|l|}
\hline Name & Age & $\begin{array}{l}\text { Level of } \\
\text { education }\end{array}$ & $\begin{array}{l}\text { Marital } \\
\text { status }\end{array}$ & $\begin{array}{l}\text { Church } \\
\text { affiliation }\end{array}$ & Location \\
\hline Mrs A & 60 & Secondary & Married & $\begin{array}{l}\text { Former } \\
\text { Zionist }\end{array}$ & Rural \\
\hline Miss B & 45 & Primary & $\begin{array}{l}\text { Single } \\
\text { parent }\end{array}$ & Zionist & Rural \\
\hline Mrs C & 56 & Primary & Divorced & Charismatic & Rural \\
\hline Mrs D & 51 & $\begin{array}{l}\text { No formal } \\
\text { education }\end{array}$ & Married & Charismatic & $\begin{array}{l}\text { Semi- } \\
\text { urban }\end{array}$ \\
\hline Mrs E & 62 & Primary & Married & Charismatic & Rural \\
\hline Mrs F & 50 & Secondary & $\begin{array}{l}\text { Married, } \\
\text { but single }\end{array}$ & Zionist & Rural \\
\hline Mrs G & 48 & Secondary & Married & Charismatic & $\begin{array}{l}\text { Semi- } \\
\text { urban }\end{array}$ \\
\hline Miss H & 38 & Tertiary & Single & Zionist & Urban \\
\hline Miss I & 45 & Secondary & $\begin{array}{l}\text { Single } \\
\text { parent }\end{array}$ & Charismatic & Rural \\
\hline Mrs J & 65 & $\begin{array}{l}\text { No formal } \\
\text { education }\end{array}$ & Married & Methodist & Rural \\
\hline
\end{tabular}

A key characteristic of feminist research is creating a safe and welcoming space for women to share their experiences and narratives (Nadar 2014). Primary data was produced through face-to-face semi-structured interviews with 10 female participants who were active members of the MPG group. I awarded participants alphabetical code names, as given in Table 1 . The interviews were conducted in places where these participants felt relaxed. Some preferred their homes, whilst others chose to meet at their respective churches. Permitting them to choose their own spaces, where they would be comfortable and more inclined to speak, was important, because the place where an interview is carried out has an impact on the responses participants provide (Patton \& Cochran 2002). Establishing good rapport with the participants yielded good results. Prior to the interviews I had initiated open communication, even on other gender issues that were not directly related to 
this particular research investigation. My position as a feminist researcher was made clear to the participants from the outset.

Furthermore, as far as possible, distractions and interruptions were eliminated during interviews (Creswell 2003). Employing attentive listening skills allowed me to probe participants' responses further through prompts and interjections, to allow for personal reflections. I was also a participant observer in some of the church services, where I had an opportunity to listen to the testimonies that members of the prayer group, amongst them the women profiled in Table 1, shared. Other people like the praise singer and song leaders were interviewed when I attended the church services. Since there was no documented history of the group, I relied on primary sources to learn about its history, development and ethos, which will be discussed in following sections.

\section{Establishment of Mhlabuhlangene Prayer Group}

In Swaziland, there are a number of prayer groups that are Pentecostal in character and they are under the leadership of women. They include Bafati Bentsaba (Women of the Mountain), Bafati Bendwayimane (Women of the Catapult), Bafati Bazwelonke (Women of all Nations) and Women of the Well. Affiliation to these groups is also open to youth and men. Although it is mostly women who are at the forefront of initiating interdenominational Christian formations of this nature, there are some that are established by men, among which are Umkhobo (Zombie), Restoration International and Amatshe Evangeli (Stones of the Gospel).

The establishment of MPG illustrates the African women's pneumatological perspective which emphasises women's experiences of the Holy Spirit in their important roles as active participants in women-led churches. Data collected from the participants of the study reveal that the origin of MPG is attributed to a revelation that the founder, Make Shongwe, had in the late 1990s. The group's name, Mhlabuhlangene, refers to the nature of its membership, namely, women of different denominations and social classes. MPG is led by Make Shongwe of Etiyeni in Swaziland, who is popularly known as Make (Mother). This designation is in the nature of a title that represents her authority over every member of the group.

Participants Mrs A, Mrs C and Miss I shared the narrative of how Make Shongwe formed the group. She lived an ordinary life, but was a daughter of a traditional healer. She was her father's helper in healing, known as 
nyankwabi. A certain Christian preacher who wanted to settle down in marriage went out to the mountains to pray to God for a wife. God revealed Make Shongwe to him, and said that she would be his future wife. The preacher then approached Make Shongwe's family and asked for her hand in marriage. At first, she was reluctant, because the man was advanced in years. She later accepted the proposal and they were married. Then, she was saved and, according to four of the participants, Mrs A, Miss B, Mrs G and Mrs J God called her to form an interdenominational women's prayer group that would be an alternative to the 'civilised' Christianity practiced in churches. The definition of 'civilised' Christianity given by the participants is the type that critically questions cultural norms and values, and whose practitioners are insensitive to God's voice, which is meant to direct them, even in mundane affairs.

It is clear from the data that Make Shongwe, after her experience with the Holy Spirit, was more inclined to founding a spiritual movement that would condone and cushion patriarchy, than to dismantle its mechanisms. This is incongruent with the tenets of African feminist pneumatology, which, at its core, seeks to empower women to resist unjust structures, and to liberate them from oppressions endorsed by patriarchally-oriented societies. Kaunda and Phiri (2016) and Mwaura (2005) agree in this regard, and claim, furthermore, that the Holy Spirit distributes spiritual gifts equally, so that women can function in equality with their male counterparts. Women at MPG seem to take the opposite view; they are content and protective of religio-cultural constructions, which, when viewed with feminist lenses, can be considered oppressive to women.

According to Mrs A and Mrs C, at the establishment of the group, there were six women, but membership in 2019 had swelled to 400 members all over the country, especially in remote areas. Participants' demographic details in the profile table illustrate this claim, with eight of the 10 participants residing in rural areas. However, participants were quick to clarify that the members of the group were affiliated with their own churches, and that MPG was only an interdenominational prayer group that met on the fifth and seventeenth days of each month to pray. On the fifth day, they fasted and prayed specifically for all Swazi children, whilst on the seventeenth, during all night prayers, they pleaded for God's interminable protection over their lives and the entire Swazi nation. They also prayed for Make, asking God to grant her the wisdom to teach members the authentic 'old-time religion'. The group does not have a specific gathering place for their prayers; they meet at any homestead where they are 
invited. Every Monday, the founder hosts deliverance sessions at her homestead, where she prays for the sick and demon-possessed. Mrs D listed the demon-related ailments that Make heals, which include women's barrenness and infertility, and broken marriages. Jules-Rosette (1985:93) refers to these ailments as 'culturally perceived illnesses'. Jules-Rosette adds another dimension, explaining that female healers provide alternative medical care, spiritual healing and services equivalent to psychotherapy and group therapy, especially for those who cannot afford the high cost of professional services. Women living in a society where power relations are skewed, where they are socialised to accept their inferior status, and to feel responsible for any social ill, therefore, escape to Christian formations such as MPG, where they find solace and therapy.

\section{The Ethos of Mhlabuhlangene Prayer Group}

As is the case with most NPCs that are led by women, in which women play prominent roles, and which elevate the uniqueness of women, MPG is led by a female founder. Make Shongwe serves as pastor, evangelist, healer, mother, prophetess, and overseer. Women, who make up the majority of the prayer group, are given leadership titles, though they are subordinate to those of the founder. According to the participants, MPG is not a splinter group of any existing church or foundation, but unites women from diverse Christian backgrounds at grassroots level. Members remain active in their congregations, even though their involvement in the prayer group is sometimes not approved by their church leaders ${ }^{4}$. The group has a strong spiritual identity, and it does not claim to be a church; hence, the group does not hold activities on Sunday mornings. After the group's weekend all-night prayer meetings, members return to their homes so that they would attend their usual church services the next day. As stated earlier, MPG is neo-Pentecostal in outlook. Whilst it is not a church in a formal sense, it draws its worldview from Pentecostalism, by emphasising the receiving of certain gifts of the Spirit, such as speaking in tongues, prophesying and healing, as signs of the baptism of the Holy Spirit. Members of the prayer group rely largely on revelations that involve the Holy

${ }^{4}$ Mrs. D. explained in interviews conducted at Ticantfwini in the outskirts of Manzini on 5 February 2018 that members still remain active at the local churches. 
Spirit, through an inner voice, speaking to them, and abiding by these revelations. Whilst much depends on the ingenuity of the group's female leader in interpreting the revelations, members acknowledge the Holy Spirit as the source of their gifts of vision, prophetic utterances and healing. The founder is extremely important to the members, and she has surrounded herself are a small group of women that forms a nucleus; hence, she is referred to as Make.

MPG is growing fast because it emphasises the good things in life that an indigenous Swazi appreciates: good health, a long life, children and titles. As noted by historian David Maxwell (1998), any brand of religious formation that fails to take cognisance of these needs is bound to lose its hold on its members. MPG's African ethos is also evident in the members' consciousness of malevolent spirits, which the mission churches scarcely acknowledge as being real. The messages members receive through revelations address the fears and trials facing a Swazi, and provide protection against such evil forces. Hence, Swazis see evil spirits everywhere, which, they believe, should be exorcised through fasting and prayer. Coupled with this belief is the ministry of faith healing, which forms a central part of the life of many NPCs. Members of MPG and their leader, discern the causes of illnesses or diseases through prophecies, visions and dreams. They proclaim that ailments are caused by demons, and that people should defy Western medical care to be cured. This is the reason why the prayer group attracts mostly underprivileged people, who cannot afford nor have access to Western medicine. It is plausible that members' perspective on cosmic forces resonates with what African feminist pneumatology identifies as a basic tenet of African spirituality, which upholds the importance of maintaining harmony or balance between spiritual forces and human beings, whilst sustaining social relationships between God and human beings (Magesa 1972).

\section{Beliefs and Practices of MPG}

The beliefs and practices of MPG reveal the core of the African feminist pneumatological perspective, which is based on the women's experience of the Holy Spirit. For women of MPG, the Holy Spirit communicates as a voice. According to the participants, honouring God's authority, and allegiance to his voice, is the core of MPG. Thus, members start their prayer services by giving praise to God through special people designated timbongi (praise singers). These praise singers wear a special black-and-white uniform, which, 
participants claimed, the Holy Spirit indicated to the founder committed members of the group should wear. This item on their programme is done in the traditional Swazi style: usually, timbongi sing praises to the king before he addresses the nation. At the prayer meeting, praise singers are accompanied by vibrant singing; the group sings songs that represent their diverse church backgrounds. When I had attended one of the services in Matsapha I interviewed the praise singer who equated the singing of praises to usual Swazi practice. In her words she said;

Sicala ngekubongelela Nkulunkulu, sisho tibongelelo takheletimfanele kuze kutsi naye abone kutsi sinenhlonipho lenkhulu kuye. Njengoba nemaSwati nawo abongelela inkhosi yawo, natsi senta njalo [we start every service with the singing of praises to our God, because we want to show Him that we love and respect Him, just like the Swazis do to their king, we also do the same $]^{5}$.

The vibrant worship at MPG confirm Hackett's assertion in Women and New Religious Movements (1987), that worship provides women with an opportunity to achieve spiritual rejuvenation and escape from the drudgery of life, as the service is participatory. Furthermore, the singing creates a sense of community, because women are able to express themselves freely through singing, dancing, prayer, sharing testimonies, and ecstatic experiences, such as falling into trances, speaking in tongues and prophesying (Hackett 1987).

Participants revealed that MPG does not have structured theological beliefs, as churches do; instead, members embrace any belief that the Holy Spirit reveals, especially to the founder and the prophetesses who work closely with her. Mrs E cited a revelation that she had received from God, which opposed them visiting hospitals to seek medical attention. In a dream, God instructed her to relay to the group that He was disappointed to see Christians queuing with others in hospitals and clinics for medication. According to God, these Christians had little faith, because they failed to trust in God's power to heal all ailments. Since that encounter with God, the participant claims to have avoided hospitals. Taking their cue from that revelation, members of the prayer group are taught to fast and pray to God to be delivered from diseases.

${ }^{5}$ Personal interview conducted in June 52016 with one of the praise singers, whom I requested to interview when I attended a prayer session in Matsapha. 
As the group engages in deep prayer, more members typically receive revelations that continue to shape their spiritualties. Mrs C, Mrs J and Miss I cited another revelation that stopped members from using hair products. Miss I in particular, claimed to have heard a voice that instructed her to go to Manzini (Swaziland's second-largest city) bus station and look on people's heads. While she was at that busy place, she saw mucus covering people's heads, and a voice told her that this was how disgusting it was in God's eyes when women apply hair products to their heads. The voice also told her that the chemicals used in the hair products originated from a snake called Oliyovo.

It also transpired from the discussions with participants that members of the group do not use contraceptives for family planning. God had revealed to one of the members that He opposed family planning. Further information on revelations and how members of the prayer group experience God was shared as testimonies.

\section{The Women's Experiences of God}

As stated earlier, the article is premised on storytelling, as a key method used by African women to make theological sense of their experiences in patriarchal societies. The following stories are drawn from testimonies of four women I listened to when I was a participant observer in one of the group's prayer meetings. The four participants are those I coded in the profile table as Miss B, Miss C, Mrs D and Mrs F. These testimonies depict the group's beliefs and practices.

\section{Mrs. F.}

Mrs $F$ testified about the importance of children in the family, thereby discrediting the use of contraceptives. She claimed that, whilst in a trance, she heard a voice instructing her to go to a certain secluded room, where she found new-born babies, singing a hymn with sweet voices. Fascinated, she asked who these babies were. The voice said that all these were babies that had been deprived of their divine right to be born in the physical world because their parents chose to use contraceptives. According to the voice, every woman was created by God to give birth to a certain number of children that would populate the physical world; failing which, the children would be born and live in the spirit world. On judgment day, mothers would meet these babies and the 
mothers would face God's punishment. The voice declared, furthermore, that Mrs F should not concern herself about contracting sexually transmitted diseases (including the deadly HIV/AIDS), because, as a prayerful woman, she was immune; even if her husband contracted diseases from someone else, the virus would burn into ashes whenever Mrs F was sexually intimate with her husband.

\section{Miss B.}

Miss B testified against seeking medical attention. She cited an incident, of a young girl who claimed to have been once a Satanist residing in spirit in the underworld. The girl revealed that there were nurses in the underworld who worked as agents of Satan in hospitals. These nurses were informed when a Christian would visit the hospital for medical attention. They would then be instructed to kill that person because he/she is a threat to Satan's kingdom; hence, mysterious deaths at hospitals. The girl also claimed that Satanists kept record of powerful Christians on their computers; thus, it was important for members to pray for God to protect them against evil spirits.

\section{Mrs. C.}

Mrs $\mathrm{C}$ heard a voice while she was pregnant, which communicated that she should not seek medical care for the whole duration of the pregnancy, because God would take care of the baby. She was instructed that a hospital was a place for people who did not trust in God's power to protect them. Consequently, she did not visit the hospital, and when her labour started, she locked herself inside her house and waited for the baby's arrival. As the pains intensified, the voice reassured her that she would have a normal delivery. Unfortunately, the baby died because of the lengthy labour. Nevertheless, she claimed to have derived strength from the fact that she, at least, had obeyed God's voice by not going to hospital.

\section{Mrs. D.}

Mrs D spoke strongly against divorce, reporting that God hated it. She invited all those who were struggling in their marriages to attend prayers on deliverance at Make's homestead. She told the group that marriages were 
destroyed by evil spirits in the form of snakes. These snakes were responsible for divorces in families. The snake takes the place of the man of the house, leaving the husband no choice but to leave, opening a space for the snakes (evil spirits). Adamant men who refuse to leave, would be killed by the snakes. Mrs D cited evil products that are associated with snakes, which members should not use, including Tupperware kitchen items, mayonnaise, eggs and broiler chickens. Regarding Tupperware, she claimed that there was no physical address of the factory where the items are produced, which was proof that the products were manufactured in the underworld, therefore,

Wonkhe umuntfu lona Tupperware kakhe akati kutsi ufuye tinyoka, ngoba uma unetikhfthini litilishumi, kusho kutsi unetinyoka letilishumi [Everyone who owns Tupperware items should know that she has domesticated snakes; if you have 10 Tupperware dishes, you own 10 snakes].

What sense do we make of the data above in relation to what the paper seeks to unearth? The following section addresses this question in thematic forms.

\section{Discussion}

\section{Women's Leadership in a Patriarchal Space}

As alluded to in the theory section, one of the frameworks premising this paper is the African feminist pneumatological perspective. This perspective emphasises women's experiences of the Holy Spirit, and recognises their leadership roles in religious spaces. Equally, African women's anthropology critically engages patriarchal structures that institutionalise women's inferiority and promotes gender disparities. The core purpose of this article is to demonstrate how women, as members of MPG, conform with patriarchy through their practice of spirituality. Their constructions of themselves and their leadership are shaped by sociocultural nuances, the very fabric that has been woven by men, for males and to support men; hence, women's continued cooperation with the patriarchy (Lerner 1986). Even when women operate within their own leadership spaces, they are conditioned by patriarchal perspectives and power structures to maintain the status quo. They operate within the parameters of dominant patriarchal ideologies, which inform expressions of their spirituality, and their rational choices. As shown by the 
data, the women's thought patterns on authority and leadership duplicate those defined by the men-dominated society, and they practice their leadership roles within the boundaries marked by patriarchy.

Mackenzie (1996:95) identifies four female leadership style categories amongst women clergy, namely, sister, girlfriend, the queen mama and wise woman. She explains each as follows:

The sister/girlfriend is usually an active member of any group. The queen mama/leader reigns supreme over the organization or church ... as mama she has everyone organised from the youngest to the oldest, everyone has responsibility in the church, tasks are assigned and mama lovingly sees them through ... no one can refuse mama anything... you can be fifty years old and still be one of mama's children ..., the wise woman is the sage... she is not always buddy-buddy with everyone and she does not act as a mother figure. This leader is able to apply social knowledge and experiences. Her wisdom can be legendary and everyone seeks her advice and counsel.

This categorisation applies to MPG, where Make Shongwe exhibits a queen mama leadership style. She sees the church as her family and she assumes the role of nurturer, by taking care of the personal and existential needs of followers. She empowers women at grassroots level by providing them with a forum where they can freely express prophecies and revelations, and they act on what the voice they hear instructs. Women also find liberation from the ever-present fear of evil spirits and other oppressive forces, through deliverance and prayer. These Christian formations, therefore, serve as a vehicle of empowerment that raises the women's status within their self-crafted sphere of influence.

However, this type of leadership can also be construed as paternalistic, with roots in patriarchy. Paternalistic structures, according to McKenzie (1996), do not question the status quo or the legality of power; instead, leadership is built around the authoritative idea that the leader is the one who has the final say in decision-making. Consultation may not even be necessary, as the leader is expected to make choices that will benefit subordinates. It is assumed that the leader puts the wellbeing of the subordinates at the centre of decision making. As shown by data, Make shares a paternalistic relationship with the members of MPG, and she is admired and celebrated as an ordained woman of God. 
Practices and beliefs of the group also provide evidence that its formulations of power are based on patriarchal frameworks. There is a divinely ordained hierarchy - God and the Holy Spirit in the form of a voice and Make - which may not be challenged. This is reflected in the worship procedure, during which members sing praises to the leader, as it is done for leaders such as kings; praises are sung as acknowledgement of authority, and as a sign of allegiance to his or her leadership.

\section{Family as an Institutional Space}

Family is an important institutional location in patriarchy; Moyo (2004) identifies it as one of cultural structures used by older women to socialise girls and younger women into being acceptable women and custodians of acceptable societal norms and values. Family is, in fact, the first environment where girls are socialised in cultural norms and values. Both girls and boys are oriented in gender roles, which are accompanied by a rigid labour distribution. Duties and responsibilities, as defined by gender roles, are perceived to be 'natural, divine and unchangeable', and anyone who transgresses the gender limits is labelled as socially deviant (Lerner 1986:16). In the Swazi context, the family is an institution that produces, reinforces, and reproduces social relations, rendering it the breeding ground for patriarchy. Patriarchy emphasises a hierarchical family order, which it regards as the natural command ordained by God. The kernel of patriarchy, as discussed by feminist theologians, is that someone has to be in charge in any given situation, and that a person's authority demands unquestioning obedience (Ngcobo 2007). This mindset permeates to people's subconsciousness, such that they find it natural to be subservient to leadership. Religious people even promote a biblical hermeneutics that bargains with patriarchy, that it be internalised as legitimate by women (Kanyoro 2001). What we, therefore, observe in MPG is a strong belief in leadership, where the designation Make goes beyond its biological function to define the founder's leadership position and authority. She commands a great deal of respect from followers, who would not challenge her on anything, lest they offend God.

\section{Women and their Natural Beauty}

As shown by the data, women at MPG do not relax their hair, so as to maintain their natural appearance. Swazi society defines beauty and good character in 
terms of a woman's appearance, therefore, women feel obliged to abide by societal standards. This is another way women negotiate with patriarchy, as they act to confirm that the female body is a cultural artefact, defined in response to sociocultural perceptions. In a patriarchal society, a woman's appearance is determined by a plethora of external forces, the core belief being that the woman should have a certain body type (Tshegofa 2004). However, what is attractive varies from one culture to another. A woman's beauty involves people's perceptions, imagination, emotions and physical sensations about a woman's body in relation to values that are not necessarily innate, but learned or expected culturally. Women tend to internalise these beauty ideals through social enforcement, whose agents are social, institutionalised locations, such as family, church and school (Tshegofa 2004). Even women who create leadership spaces within their territory, are stereotypically expected to have a certain appearance, in order to conform to a certain ideal. Thus, a woman's body can never be a neutral entity; someone has to have some kind of control (Tshegofa 2004).

Members of MPG perceive adorning the feminine body as an evil act that is intended to, indecorously, attract people's attention, especially that of men; thus, a sign of a woman's sexual immorality. This belief is not different from imposing beauty ideals on women, which is part of a patriarchal discourse. African women's anthropology critiques the stereotype that women are Eve's incarnates and bearers of sin (Oduyoye 2001). For Acolatse (2001), such dehumanising stereotypes have pushed women to a fatal resignation to the status that is prescribed by men in patriarchal societies.

\section{The 'Child Factor Syndrome'}

African feminist scholars identify woman's fertility as being crucial in patriarchal societies for the survival of the family or clan names, and for the incarnation of family ancestors, which Oduyoye (1999) calls the 'child factor syndrome', which is prevalent in African families. Swazi society attaches high value to motherhood, which entails the woman's capability to bear children for her marital lineage, and nurturing. As a result of societal beliefs and norms, children enable women to view themselves as 'full' women who perpetuate the family name through their male children (Nyawo 2013). In other words, women themselves construct their personhood around their ability to procreate. They internalise the dynamics of the male-dominated social hierarchy, which 
subsequently shapes their self-conceptualisation that they can only be appropriately defined by childbearing (Kwok 2004). A woman's fertility accords her 'high quality' status in her family, especially if she produces an 'heir' (Nyawo, Nadar \& Reddy 2013). The family is assured of its continuity and its permanence in its ancestral residence. Motherhood is, therefore, a highly valued role that is open only to women, but desired by both men and women, indeed, the entire society (Oduyoye 1999).

The cited testimonies illustrate the women's beliefs on threats to their reproduction assignment, which renders them relevant in the patriarchal space. Thus, they need to create cautionary stories about contraceptives, so as to discourage women from using contraceptives for family planning, as captured in the data.

Feminist theologians criticise cultural undercurrents that relegate women to a second class in the social hierarchy, which indoctrinate women to think first and more about the next person than themselves (Mate 2002). In relation to their role as child-bearers, for instance, they are concerned that the man's name will be forgotten after he dies if a woman fails to give him a child. She is even willing to sacrifice her dignity and happiness to rescue the man from shame. So, having children is not about her, it is about him (Nyawo 2013). Nadar and Potgieter (2010) are, therefore, right when they observe that women are brought up from the very earliest years in the belief that they are to sacrifice their happiness and live for others, and to have no life except one based on giving affection. In childhood, a girl is made aware of her destiny, that she is a wife-in-waiting who is being prepared for the role of motherhood, which she will fulfil elsewhere, away from her parental home and for the purpose of the community Ngcobo (2007). In MPG, therefore, women's perceptions of themselves and their social roles are shaped by traditional thought patterns on motherhood that reinforce patriarchy.

\section{Conclusion}

MPG, as an ecumenically inclusive Christian fellowship, thrives in a context that is patriarchal in its institutions, ideology and distribution of power. In Christian spaces, patriarchy is not viewed as merely a social phenomenon, but a God-given directive and order for society to function properly, and this directive inspires unquestioned commitment. Women in new Christian formations, like MPG, therefore, conform, and lead and function within 
patriarchy, instead of challenging it; thus, expressing their spirituality in between the poles of patriarchy. One challenge posed by patriarchy is that, as Lerner (1993) observes, it is not a one-day event; it has developed over a period of many years, at different times and places. As a deeply rooted social construct, patriarchy manages to exert pressure on Christian women to internalise its ideologies, thereby, knowingly or unknowingly, recreating patriarchy every day. Patriarchy derives strength from managing to adapt and find expression in ever-changing sociopolitical and religious spaces. However, this does not repudiate the argument that there has to be more productive ways to empower Christian women to fight against the injustices of patriarchy.

As women-led Christian expressions such as MPG continue to grow with vibrancy and enthusiasm, is the patriarchal agenda being ripped to shreds or reshaped? Evidence presented throughout the paper reveals a desperate need for a prophetic voice that will critically engage patriarchy through the feminist lens, to realise complete empowerment for women.

This voice should justly and deservedly reprove the injurious hermeneutics that patriarchy has imposed on both culture and religion, whilst advocating for a liberating hermeneutics. Liberating hermeneutics is referred to by African feminist scholars as cultural hermeneutics. They motivate that it is key to the liberation of women in Africa, because it opens the eyes of African women, so that they do not succumb blindly to patriarchal sociocultural and religious agendas: 'it is meant not only to counteract the oppressive impact of the Bible, but to create hope and a will to change oppressive situations and structures' (Hinga 1990:34), thus, affirming women's human dignity personhood.

\section{References}

Acolatse, E. 2001. Rethinking Sin and Grace: An African Evangelical Feminist Response to Niebuhr. In Njoroge, J.N. \& M.W. Dube (eds.): Talitha Cum!: Theologies of African Women. Pietermaritzburg: Cluster Publications.

Anderson, A. 1995. Challenges and Prospects for Research into African Initiated Churches in Southern Africa. Missionalia 23,3: 283 - 294.

Asamoah-Gyadu, K.J. 1998. Fireballs in our Midst: West Africa's Burgeoning

Charismatic Churches and the Pastoral Roles. Mission Studies XV-1,29:

15 - 31. https://doi.org/10.1163/157006608X262728

Asamoah-Gyadu, K.J. 2000. Gender, Social Change and Spiritual Power: 
Charismatic Christianity in Ghana. Journal of Religion in Africa 38,1: 98 $-99$.

AWEPON (African Women's Economic Policy Network) 2005. A Baseline Study of the Socio-economic Impact of HIV and AIDS and the Responsiveness of Policy Framework Swaziland. Mbabane, Swaziland: AWEPON.

CEDAW (Convention on the Elimination of All Forms of Discrimination against Women) 2011. Gender, Leadership and Advocacy for Members of Parliament. Workshop Proceedings.

Creswell, J.W. 2003. Research Design: Qualitative and Quantitative Approaches, $2^{\text {nd }}$ edition. Thousand Oaks, CA: Sage.

Hackett, H. 2000. Women and Romance Fiction in the English Renaissance.

Cambridge: Cambridge University Press.

https://doi.org/10.1017/CBO9780511518904

Hackett, R. 1987. Women and New Religious Movements in Nigeria. Lewiston, NY: Edwin Mellen Press.

Hinga, T. 1990. Women's Liberation In and Through the Bible: The Debate and the Quest for a New Feminist Hermeneutics. African Christian Studies 6, 4: 32 - 49.

Hollenweger, W.J. 1972. The Pentecostals. London: SCM Press.

Hollenweger, W.J. 1997. Pentecostalism: Origins and Developments Worldwide. Hendrickson Publishers.

Jenkins, P. 2000. The Next Christendom: The Coming of Global Christianity. Oxford: OUP.

Jules-Rosette, B. 1985. Cultural Ambivalence and Ceremonial Leadership: The Role of Women in Africa's New Religious Movements, in the Church and Women in the Third World. In Webster, J.B. \& E.L. Webster (eds.): The Church and Women in the Third World. Philadelphia: Westminster Press.

Kanyoro, M.R.A. 2001. Engendered Communal Theology: African Women's

Contribution to Theology in the Twenty-First Century'. Feminist Theology 27: 36 - 56. https://doi.org/10.1177/096673500100002704

Kaunda, C.J. \& I.A. Phiri 2016. African Instituted Churches' Pneumatology and Gender Justice in the Work of G.C. Oosthuizen: An African Feminist Pneumatological Perspective. Scriptura 115: 1 - 12.

https://doi.org/10.7833/115-0-1290

Kingdom of Swaziland 2007. Population and Housing Census. Volume 6. 
Mbabane, Kingdom of Swaziland: Central Statistical Office.

Kwok, P. 2004. Mercy Amba Oduyoye and African Women's Theology. Journal of Feminist Studies in Religion 20,1: 7 - 22.

Lerner, G. 1986. The Creation of Patriarchy. New York: Oxford University Press.

Lerner, G. 1993. The Creation of Feminist Consciousness: From the Middle Ages to 1870. Oxford: Oxford University Press.

Magesa, L. 1997. African Religion: The Moral Traditions of Abundant Life.

Maryknoll, NY: Orbis Books.

Malti-Douglas, F. 2007. Encyclopedia of Sex and Gender. Detroit: Macmillan. Mama, A. 2011. What does it Mean to do Feminist Research in African Contexts? Feminist Review Conference Proceedings. Available at: https://doi.org/10.1057/fr.2011.22

Mate, R. 2002. Wombs as God's Laboratories: Pentecostal Discourse of Femininity in Zimbabwe. Africa 72,4: 549 - 568.

https://doi.org/10.3366/afr.2002.72.4.549

Maxwell, D. 1998 Delivered from the Spirit of Poverty? Pentecostalism,

Prosperity and Modernity in Zimbabwe. Journal of Religion in Africa XXVIII,3: 351 - 373.

https://doi.org/10.1163/157006698X00053

McKenzie, V.M. 1996. Not Without a Struggle: Leadership Development for African American Women in Ministry. Cleveland: United Church Press.

Moghadam, V. 2005. Globalizing Women: Transnational Feminist Networks. Baltimore: Johns Hopkins University Press.

Moyo, F.L. 2004. Religion, Spirituality and Being a Woman in Africa: Gender Construction within the African Religio-cultural Experience. Agenda: Empowering Women for Gender Equity 18,61: 72 - 78.

Mpofu, J. 1983. Some Observable Causes of Women's Subordination in Zimbabwe. Harare: Cass.

Mwaura, P.N. 2005. Gender and Power in African Christianity: African Instituted Churches and Pentecostal Churches. In Kalu, O. (ed.): African Christianity: An African Story. Pretoria: University of Pretoria. https://doi.org/10.3366/swc.2004.10.2.160

Nadar S. \& C. Potgieter 2010. Liberated through Submission? The Worthy Woman's Conference as a Case Study of Formenism. Journal of Feminist Studies in Religion, 26,2: 141 - 151.

https://doi.org/10.2979/fsr.2010.26.2.141 
(Accessed on 10 September 2019.)

Nadar, S. 2009. Her-stories and Her-Theologies: Charting Feminist Theologies in Africa. Studia Historiae Ecclesiasticas 35,December: 135 - 150.

https://doi.org/10.1080/10130950.2014.871838

Nadar, S. 2014. Stories are Data with Soul: Lessons from Black Feminist Epistemology. Agenda: Empowering Women for Gender Equality 28,1: $18-28$.

Ngcobo, L. 2007. African Motherhood Myth and Reality. In Tejumola O. \& A. Quaysin (eds.): African Literature: An Anthology of Criticism and Theory. Malden: Blackwell Publishing.

Nyawo, S. \& N. Nsibande 2014. Beyond Parity: Gender in the Context of Educational Leadership in Swaziland. UNISWA Research Journal Special 27,March: 45 - 58.

Nyawo, S. 2013. Sowungumuntfu ke nyalo - 'You are Now a Real Person': A Feminist Analysis of How Women's Identities and Personhood are Constructed by Societal Perceptions on Fertility in the Swazi Patriarchal Family. PhD thesis. University of KwaZulu-Natal, Pietermaritzburg.

Nyawo, S., S. Nadar \& S. Reddy 2013. Sowungumuntfu ke nyalo - You are Now a Real Person: Reproductive Self-Determination in the Context of Reproductive Health in Swaziland. Journal of Gender and Religion in Africa Special Issue 19,2: 105 - 118.

Oduyoye, M. 1995. Daughters of Anowa: African Women and Patriarchy. Maryknoll, NY: Orbis Books.

Oduyoye, M. 1999. A Coming Home to Myself: The Childless Woman in West African Space. In Farley M. \& S. Jones (eds.): Liberating Eschatology: Essays in Honour of Letty M. Russell. Louisville: Westminster John Knox Press.

Oduyoye, M. 2001. Introducing African Women's Theology: Sheffield: Sheffield Academic Press.

Patton, Q. \& M. Cochran. 2002. A Guide to Using Qualitative Research Methodology. London: Sage.

Phiri, I. 2004. African Women's Theologies in the New Millennium. Agenda: Empowering Women for Gender Equity 61,Religion \& Spirituality: 16 24.

Sanneh, L. 2003. Whose Religion is Christianity? The Gospel Beyond the West. Grand Rapids MI: Eerdmans.

Tshegofa, P. 2014. Notions of Beauty and Attractiveness. OSISA. 
www.osisa.org/buwa/regional/notions and attractivess

(Accessed on 10 September 2019.)

US Department of State 2018. 2017 Report on international Religious Freedom: Swaziland. Available at: https://www.state.gov/reports/2017report-on-international-religious-freedom/swaziland/ (Acccessed on 10 September 2019.)

Walls, A. 2002. The Cross-Cultural Process in Christian History. Maryknoll. NY: Orbis.

WCC (World Council of Churches) 2009. Ecumenical Chronicle 61,3: 343 344. https://doi.org/10.1111/j.1758-6623.2009.00031.x

WLSA (Women and the Law in Southern Africa) 2001. Multiple Jeopardy: Domestic Violence and Women's Search for Justice in Swaziland. Mbabane, WLSA Research and Educational Trust.

Zigira, C. 1998. Role of NGOs in Economic Empowerment of Women in Swaziland: A Case Study of Umtapo WaBomake in Swaziland. Addis Ababa: OSSREA.

Sonene Nyawo $(\mathrm{PhD})$ Department of Theology and Religious Studies University of Eswatini Eswatini snyawo@uniswa.sz 